\title{
'Skeuomorphs': on the rhetoric of material in the Gumelniţa tradition
}

\author{
Dragoș Gheorghiu \\ National University of Arts, Bucharest, RO \\ gheorghiu_dragos@yahoo.com
}

\begin{abstract}
The social changes, which characterise the Chalcolithic in southeastern Europe, which coincide with the emergence of metals, imposed a new material and led to the emergence of skeuomorphs (i.e. copies of objects made from a material different from that of the originals). Some gold objects from the Gumelnita tradition were objects of value, such as the valves of exotic shells, which therefore become visible in the form of paraphernalia. The present paper discusses the rhetoric of material visible in the shape and proximity of originals and skeuomorphs.
\end{abstract}

IZVLEČEK - Družbene spremembe, značilne za obdobje eneolitika v jugovzhodni Evropi, so s pojavom kovin uveljavile nov material in vodile $k$ pojavu skeuomorfizma (kopija predmeta, izdelana iz drugačne snovi kot original). Nekateri zlati predmeti v kulturi Gumelnita, kot so upodobitve lupin eksotičnih školjk, so bili dragoceni predmeti in so tako postali vidni del osebne lastnine. V članku obravnavamo retoriko snovi, razvidno iz oblike, in podobnosti med originali in skeuomorfi.

KEY WORDS - materiality; skeuomorph; Spondylus shell; gold; Gumelniţa tradition

\section{Introduction}

The last few decades illustrate how anthropological and archaeological studies of material (Renfrew, Scarre 1998; Schiffer, Miller 1999; Miller 2005; Hurcombe 2007; DeMarrais et al. 2004; Jones, MacGregor 2002; Tilley 2004; Meskell 2005; Jones 2007; Gheorghiu, Children 2011) have become more common in the field of prehistoric studies.

Materiality is extremely important, since it offers a special perspective on the relationship between material and social (Hurcombe 2007.105). Because of the large variety of materials in the Balkan and Lower Danube Chalcolithic traditions, an approach from the perspective of materiality could offer new data on the cultural problems of the emerging stratified societies of the $5^{\text {th }}$ millennium BC.

During the Chalcolithic, the raw materials used in the prehistoric world underwent a series of modifications due to the social-economic transformations that characterise the $5^{\text {th }}$ millennium in South Eastern Europe (see Bailey 2000; Müller 2012). This is the moment when a new material, i.e. metal, appeared/ came into use. Metal soon became the most important material (see Pernicka, Anthony 2010), dominating the materiality of other local or exotic objects of value.

Although not openly manifest (see Slavcev 2010), emergent social stratification (Gheorghiu 2001.375; Müller 2012) can be inferred from the spatial organisation of settlements, whose early levels are relatively standardised and ordered by geometry (see Todorova 1982; see also Chapman 2010.80), in the fortification of settlements (Popovici 2010.103), or in the removal of objects of value from the daily economy (see Ivanov, Avramova 2000) to funerary deposits, as well as the non-uniform distribution of value in funerary contexts (see Slavchev 2010.200; Lazăr et al. 2009; Comşa 1995). The relative homo- 
geneity of local and exotic objects of value could be explained by the existence of several regional settlement networks (Higham et al. 2007).

Probably the most evident exotic objects during the Neolithic (Berciu 1966; Chapman 2007) and Chalcolithic (Haimovici 2007) were exotic bivalves and scaphopods (Pope, Goto 1993), such as Spondylus gaederopus L., Glycimeris or Dentalium (Comssa 1973) imported through long-distance trade (see Séfériadès 2011). The rarity of Spondylus shells which appear as early as the Middle Neolithic - led to the emergence of copies made of marble (see Berciu 1966), an exotic material in the north of the Balkans, or to the use of fossil shells (Dimitrijevic, Tripković 2006.246).

One can imagine the great importance of exotic materials in prehistoric societies (see Chapman 2003; Chapman 2007; Vianello 2010; for the Bronze Age, see Knapp 1998) due to their symbolic value (see Claassen 1998) or, in other words, to their special materiality (Chapman 2007.212; Gheorghiu 2010.15).

\section{Skeuomorphs}

The rarity of exotic materials and the beginnings of metal working (copper and gold) were mutually influential. To meet the need for prestige objects in an emergent stratified society, one solution would have been the exploitation of copies of prestige objects made of an accessible local material, which would then lead to the proliferation of skeuomorphs, which would have replaced the scarce originals (see Gheor-

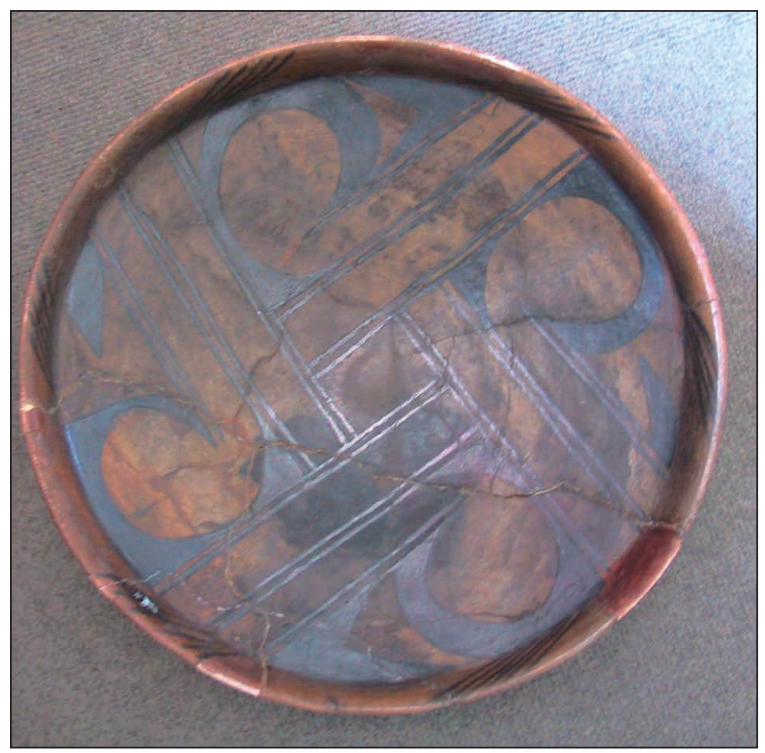

Fig. 1. Large plate decorated with graphite, Sultana settlement (Giurgiu Museum). ghiu 2010). In reality, in spite of the emergence of skeuomorphs, they did not completely replace the originals, continuing to exist alongside them.

A skeuomorph is a special case of the substitution of material, being a copy of one object in a different, usually more common, material. The reverse occurs when a common material is used to copy one of higher value, such as the gold astragal from grave 36 in the Varna cemetery.

The present paper discusses some examples of skeuomorphism from the Gumelniţa tradition, when gold replaced graphite and exotic shells.

The first example is represented by the ceramics painted with flakes of alluvial gold (Eluère, Raub 1991) from Grave 4 of the Varna cemetery (Ivanov 1988), a large plate and a small bowl with lid. In this instance, gold replaces the graphite, which would normally decorate the fine pottery. Skeuomorphs of these two ceramic pieces were discovered north of the Danube, at the Sultana tell-settlement, in the form of a large dish and a lid (Giurgiu Museum). Both objects (Figs. 1 and 2) are decorated with a graphite pattern (similar to that of the large Varna dish painted with gold), drawn on a yellowreddish ground. Experiments with up-draught kilns demonstrate that such a technical achievement was possible using a three-stage firing process, i.e. reoxidizing the objects fired in a reduced atmosphere, a process possible after three openings and closures of the kiln's apertures (Gheorghiu 2006.31); this technique would later be rediscovered in Ancient

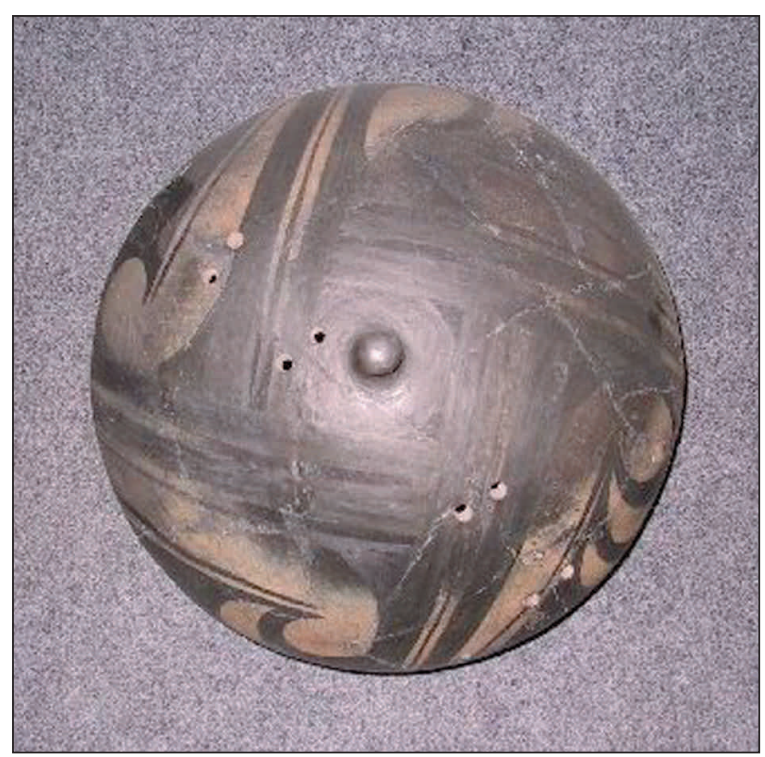

Fig. 2. Large lid decorated with graphite, Sultana settlement (Giurgiu Museum). 

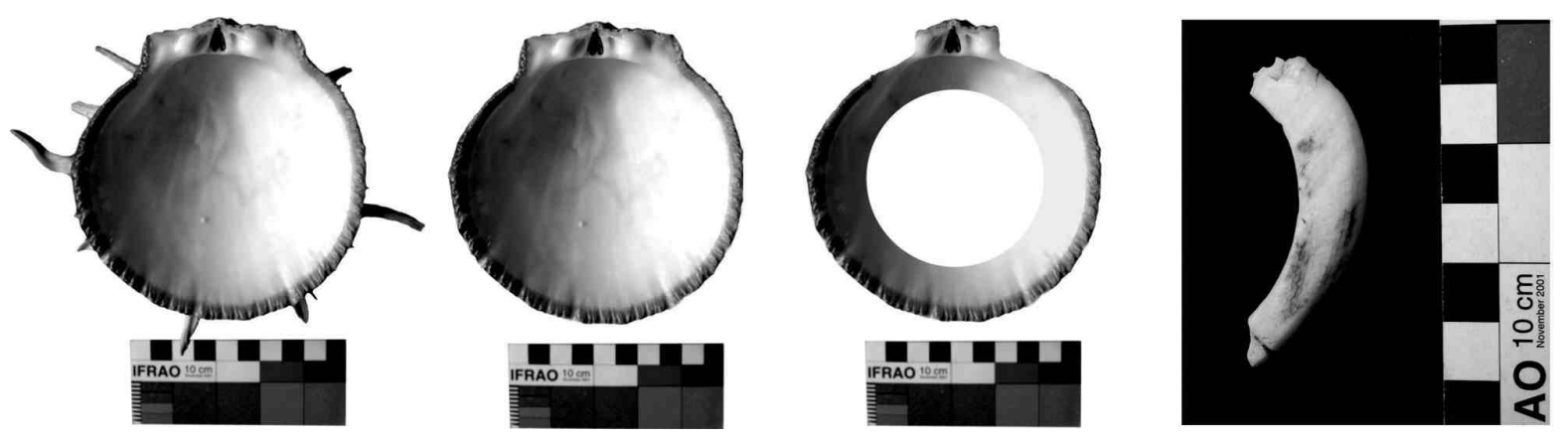

Fig. 3. Four phases in the processing of a Spondylus shell, from the valve with spikes to a fragmented ring.

Greece to produce black and red figure pottery ( $\mathrm{No}$ ble 1988).

A second example illustrates the use of gold to produce skeuomorphs of exotic shells like Spondylus and Dentalium. If the shell of the scaphopod Dentalium was used in its natural shape to form necklaces, the valves of the Spondylus shell underwent a series of operations (see Tsuneki 1989; Gaydarska et al. 2004; Kiparisi-Apostolika 2011.162), from the cutting of the spikes, to the perforation of the middle of the valve, until the final transformation into a ring/anulet, or bracelet (Fig. 3).

In the Gumelniţa tradition (at Varna, Sultana or Hotnitsa, see Fol, Lichardus 1988.121, Fig. 69) all the stages of the chaine-operatoire of the transformation of the Spondylus valves were copied in gold (Gheorghiu 2006.30; Gheorghiu, Children 2011. 19), from the moment the spikes were removed to the perforation of the middle of the valve (Fig. 4), and up to the making of rings and cylindrical beads. There is a manifest analogy between the general proportions of the shell, the shape of the umbus or ears of the valve, the shape and position of the tubercles on the interior of the left valve, and the general proportions and contours, as well as the position of the perforations of the gold pendants. For example, the central upper perforation on the gold pendant from the Durankulak necropolis (Fig. 5) could represent the monomyarian (i.e. the visible notch of the central ligament of the valve) and the two other small perforations, the prominent round teeth specific to the left valve. As for the large central perforation present on some gold pendants, it could represent a major stage in the manufacturing process of the shell to become a bracelet (Gheorghiu 2010.18, Fig. 2.9).

In the gold inventory of the Varna cemetery, one can identify all the manufacturing stages of the left valve of the Spondylus shell (Gheorghiu 2010) as described by Tsuneki (1989.9, Fig. 6) (see the gold pendants from Grave 36, in Anthony, Chi 2010. 236, Fig. 141).

An additional skeuomorph common in the Varna and Sultana hoards (Halcescu 1995) is the Dentalium tubular shell used for necklaces, which was also copied in gold. In order to suggest the segmented shape of the necklaces made of this scaphopod, narrow pieces of gold sheet were given a spiral shape (Fig. 6).

Assuming that gold was mainly used as skeuomorphic material, one can also consider the large gold bracelets and gold rings from the Varna cemetery and the Sultana hoard (Fig. 7) to have been skeuomorphs of Spondylus bracelets and rings. In support of this statement, I mention Grave 43 (see Fol, $\mathrm{Li}$ chardus 1988.9, Ill.2), which contains a Spondylus bracelet repaired (or enlarged) with gold foil, which implies compatibility between the two materials (see also Séfériadès 1995).

A comparison between the gold objects from Varna and the Sultana hoard reveals the existence in the Gumelniţa tradition of a quite uniform set of prestige objects, consisting of skeuomorphs (Tab. 1).

When gold was substituted for the material of an object, this changed the dimensions of the object being copied; for example, the skeuomorphs of whole
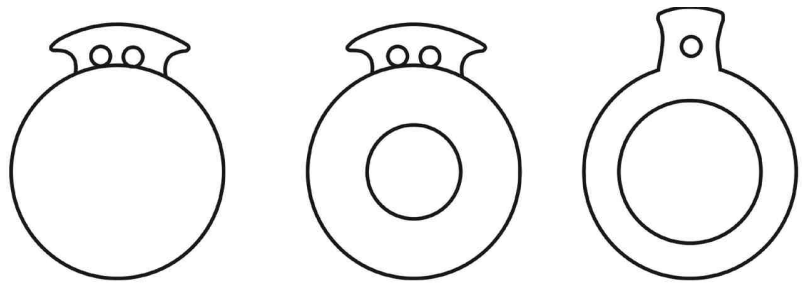

Fig. 4. Three gold pendants from Varna cemetery, showing three stages of the chaîne opératoire of shell processing (after Gheorghiu 2010.Fig. 2.10). 
valves, or valves with central perforation, are smaller than the originals, the resulting bracelets being more massive or miniaturised.

One can infer that this rhetorical process of minimisation and maximisation of skeuomorphs was because they were to be exhibited either on the body or on a costume. Examples can be found in other traditions: skeuomorphs of the exotic shell Cypraes are recorded as among brooches of the Picean culture (Landol$f i$ 2005). The small perforations in the Gumelniţa gold pieces found on human skeletons could be explained as a method of fastening on a textile surface (Gheorghiu 2010.22-23).

Ceramic vases like the large plate from Sultana have perforated protuberances on their backs, a detail indicating the vase could have been fixed to a wall.

A display of skeuomorphs of objects of value on the body or on walls could have been a message referring to the social status of the owner (Veblen 1994); for example, at the Varna cemetery the complete or metonymic images of horned animals sewn to the

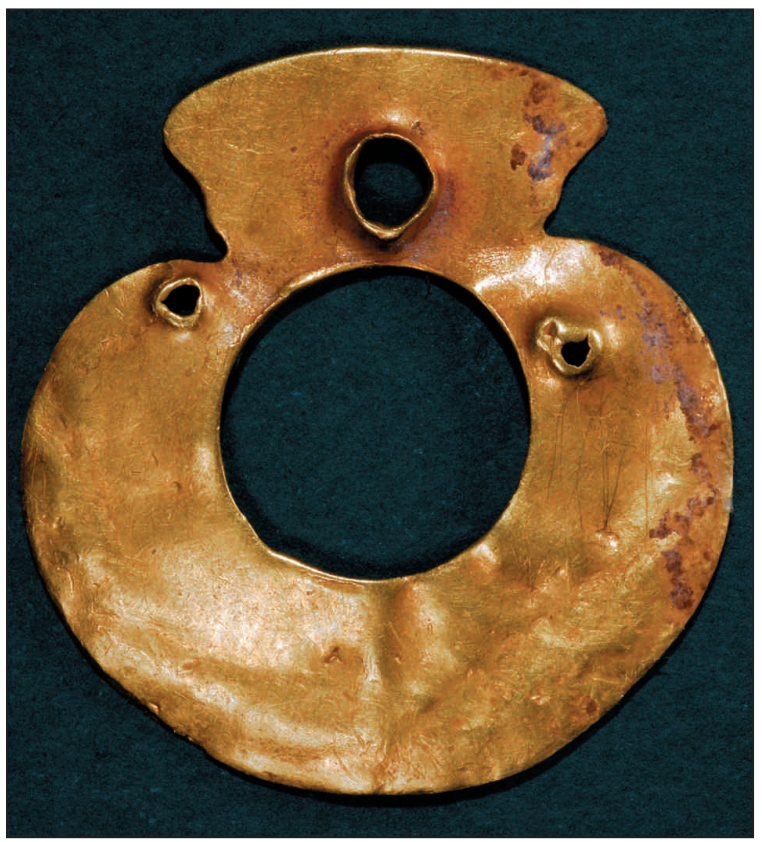

Fig. 5. Gold pendant from Durankulak cemetery (no scale) compared with the left valve of a Spondylus shell with central perforation. costume could be interpreted as an index of the owner's wealth.

A different kind of skeuomorph found at the Varna cemetery is a human figure copied in clay and positioned in cenotaphs to replace the real body. In Grave 2, the traits of the human figure were emphasised by various gold objects: a diadem on the forehead, two round pieces on the eyes, a narrow strip on the mouth, and wire rings piercing the ears (see Fol, Lichardus 1988.5, Fig. 1). The gold skeuomorphs of Spondylus shells were positioned near the chin of the clay mask.

\section{Skeuomorphic materials: shapes, colours and proximity}

A skeuomorph is an attempt to copy the shape, colour and texture of the original. For example, the colour palette at the Varna cemetery (see Chapman 2002.58, Tab. 2.1, 59, Tab. 2.2) shows the presence of colour analogies, which in most cases probably determined the selection of skeuomorphic materials: the various nuances of red of the contour of the Spondylus valves had a visual correspondent in the colour of the polished copper (for copper nuances, see Keates 2002.111), which in turn had a correspondent in the flesh-like colour of the carnelian (Rapp 2009).

These equivalent colours of copper, carnelian and Spondylus valves suggest a rhetoric of material based on analogy. There is general agreement that the study of colour in prehistory is linked in particular with texture (Lynch 1998; Jones, Bradley 1999; Owoc 2002.133; for the relation between the colour 
and texture of Gumelniţa fine ceramics, see Gheorghiu 2006); in this haptic perspective, all the colours mentioned belong to materials with a high polish.

The rhetoric of materiality is observable also in the proxemics of materials with analogous colours or textures, such as the necklaces with gold and carnelian beads (Graves 41 and 97 at Varna), or the necklace with Spondylus and copper beads (at Reka Devnja, see Fol, Lichardus 1988.102, Fig. 55).

An additional aspect of the visual rhetoric in Gumelniţa is the proximity of originals with skeuomorphs; for example, in Grave 43 at Varna, a flint arrow point and a stone axe were placed near a copper arrow point and a copper axe-hammer.

\section{Conclusion}

The emergence of skeuomorphs of prestige objects in relation to the new technology of metal manufacturing during the Chalcolithic is part of a wider phenomenon of skeuomorphism created by the process of copying (see $\mathrm{Jo}$ vanović 1996.31; Lichardus 1991) and replacing (see Siklósi, Csengeri 2011.57) common and valuable materials with metal. Although the models copied still preserve Neolithic shapes and symbols, a new material began to take over, slowly modifying the old models and suggesting new shapes. For example, at the Varna necropolis, alongside the me-

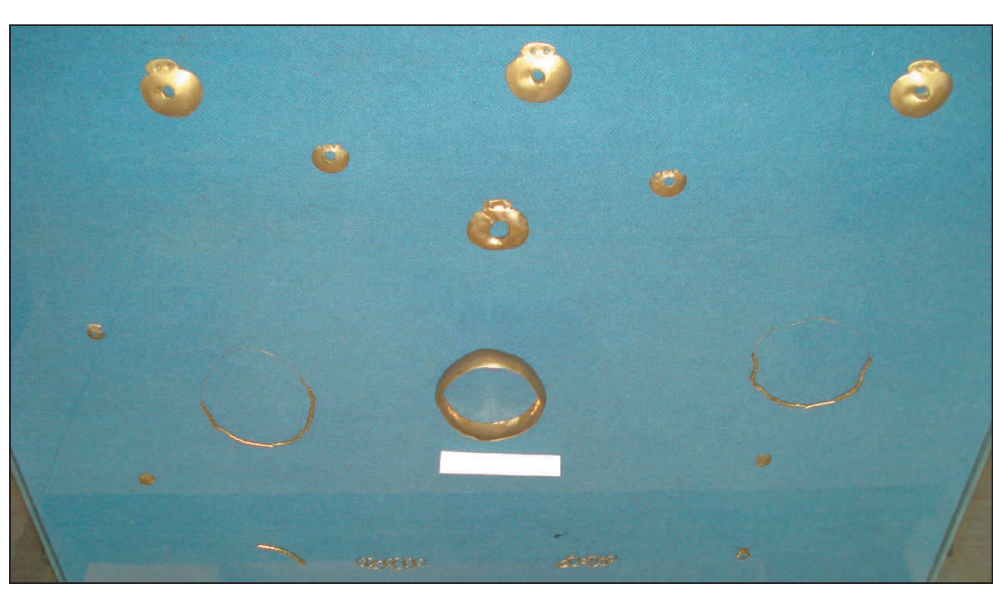

Fig. 7. Copy of the Sultana hoard, Oltenita Museum.

\begin{tabular}{|l|l}
\hline Original material & Skeuomorph \\
\hline Spondylus shell & $\begin{array}{l}\text { Gold ring bracelets (Grave 43); } \\
\text { Spondylus bracelet mended with } \\
\text { gold (Grave 43) } \\
\text { Perforated Spondylus shell }\end{array}$ \\
$\begin{array}{l}\text { Perforated gold appliqués (Graves } \\
2,15,36,97)\end{array}$ \\
\hline Curved fragment of Spondylus bracelet & Gold crescent plate (Graves 1, 143) \\
\hline Copper beads & Carnelian beads (Graves 41, 43, \\
\hline Copper & 97, 143) \\
\hline Copper/gold & Red ochre (Grave 11) \\
\hline Dentalium shell beads & Yellow ochre (Grave 111) \\
\hline Spondylus shell beads & Gold spirals (Grave 41) \\
\hline
\end{tabular}

Tab. 2. Skeuomorphic colours at Varna.

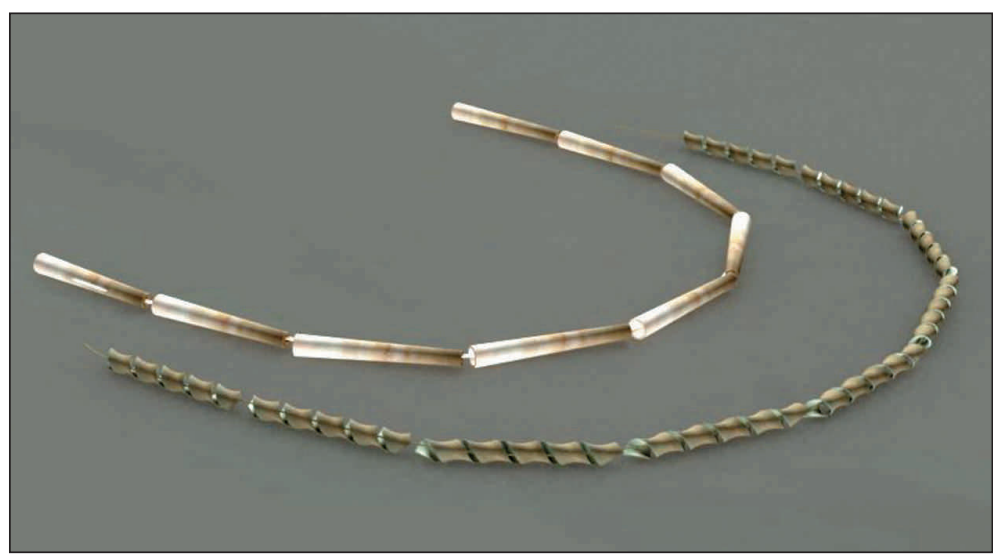

Fig. 6. Virtual reconstruction of a Dentalium necklace compared with a gold necklace with spiral strips.

tallic skeuomorphs of exotic shells, new images (such as animals and various paraphernalia) are now present. Such novel imagery does not exist at the periphery of the tradition, which used only skeuomorphs of Neolithic objects.

In the Cucuteni tradition, skeuomorphism changed more drastically the material of objects. For example, the Brad hoard (see Ursachi 1991), discovered in a Cucuteni A3 phase, and of a definite Gumelniţa influence, had an inventory analogous with that of the Varna tombs: a copper axe, two gold discs with two perforations, three copper discs and bracelets. The difference is that the Dentalium, or Spondylus beads were replaced here with a local product: deer teeth.

Analysing the Gumelniţa skeuomorphs, one can conclude that their role was to expand the set of objects 
of prestige by changing the material of these objects. Thus, the presence of skeuomorphs infers the use of a rhetoric of the copy in relationship to the original. For example, the use of gold is the rhetorical trope of copying an object in a brighter material, without rust and with a relatively effortless technique of acquisition, since alluvial gold (Koleseri 1789) was more easily found and processed than copper.

The number, material and position of the skeuomorphic accessories of the costume at Varna suggest a high degree of theatricality and performance (see Gheorghiu 2010.23). A valuable vase displayed on the walls of a house would convey a similar message.
A new material, more visible in the social spectacle (see Debord 1992) than what preceded it, announced the intention of a social transformation and a new manifestation of the concept of value.

\section{ACKNOWLEDGEMENTS}

The author thanks Professor Mihael Budja for the kind invitation to contribute, and Dr. Todor Dimov and Dr. Lolita Nikolova for permission to use the image of the gold piece from Durankulak and to Dr. Done Serbanescu and Dr. Cătălin Lazar for permission to study museum collections. Last, but not least, many thanks to Mr. Bogdan Capruciu for reviewing the English of the text. The $3 D$ reconstructions are by Christina Kudor, MA.

\section{References}

Anthony D. W., Chi J. Y. (eds.) 2010. The Lost World of Old Europe. The Danube Valley, 5000-3500 BC. Princeton University Press. Princeton and Oxford.

Bailey D. 2000. Balkan prehistory. Exclusion, incorporation and identity. Routledge. London and New York.

Berciu D. 1966. Cultura Hamangia. Noi contributii. Editura Academiei RSR. Bucharest.

Chapman J. 2002. Colourful prehistories: The problem with the Berlin and Kay Colour Paradigm. In A. Jones, G. MacGregor (eds.), Colouring the Past. The Significance of colour in archaeological research. Berg. Oxford \& New York: 45-72.

2003. Domesticating the exotic: The context of Cucuteni-Tripol'ye exchange with steppe and forest-steppe communities. In K. Boyle, C. Renfrew, M. Levine (eds.), Ancient interactions: East and West in Eurasia. McDonald Institute for Archaeological Research. Cambridge: 75-92.

2007. Engaging with the exotic: The production of early farming communities in South-East and Central Europe. In M. Spataro, P. Biagi, (eds.), A short walk through the Balkans, The first farmers of the Carpathian Basin and adjacent regions. Societa per la Preistoria e Protoistoria della regione Friulli-Venezia Giulia Quaderno 12. Trieste: 207-22.

2010. Houses, households, villages, and proto-cities in Southeastern Europe. In D. W. Anthony, J. Y. Chi (eds.), The Lost World of Old Europe. The Danube Valley, 5000-3500 BC. Princeton University Press. Princeton and Oxford: $75-89$.
Claassen C. 1998. Shells. Cambridge University Press. Cambridge.

Comşa E. 1973. Parures néolithiques en coquillages marins découvertes en territoire roumain. Dacia $N$. S. XVII: 61-76.

1995. Necropola Gumelnițeană de la Vărăști. Analele Banatului IV(1) Timişoara: 55-193.

Debord G. 1992. La Societé du spectacle. Commentaires sur la societé du spectacle. Gallimard. Paris.

DeMarrais E., Gosden C., Renfrew C. (eds.) 2004. Rethinking materiality: the engagement of mind with the material world. McDonald Institute for Archaeological Research. Cambridge.

Dimitrijević V., Tripković B. 2006. Spondylus and Glycymeris bracelets: Trade reflections at Neolithic Vinča-Belo Brdo. In M. Budja (ed.), $13^{\text {th }}$ Neolithic Seminar. Documenta Praehistorica 33: 237-252.

Eluere C., Raub C. R. 1991. Investigations of the gold-coating technology of the great dish from Varna. In J.-P. Mohen (ed.), Découverte du metal. Picard, Paris: 13-30.

Fol A., Lichardus J. (eds.) 1988. Macht, Herrschaft und Gold. Der Gräberfed von Varna (Bulgarien) und die Aufänge einer neuen europäischen Zivilisation. Galerie des Saarland-Museum. Saarbrücken.

Gaydarska B., Chapman J., Angelova I., Gurova M. and Yanev S. 2004. Breaking, making and trading: The Omurtag Eneolithic Spondylus hoard. Archaeologia Bulgarica VIII (2): 11-33. 
Gheorghiu D. 2001. Southeastern European Late Chalcolithic. In P. Peregrine, M. Ember (eds.), Encyclopedia of Prehistory. Vol. 4 Europe. Kluwer Academic/Plenum Publishers, New York, Boston, Dordrecht, London, Moskow: 367-380.

2006. On Chalcolithic ceramic technology: A study case from the Lower Danube Traditions. In D. Gheorghiu (ed.), Ceramic Studies. Papers on the social and cultural significance of ceramics in Europe and Eurasia from prehistoric to historic times. BAR IS 1553. Archaeopress, Oxford: 29-42.

2010. Insignia of exotica: skeuomorphs of Mediterranean shells in Chalcolithic south Eastern Europe. In A. Vianello (ed.), Exotica in the Mediterranean. Oxbow Books, Oxford: 13-25.

Gheorghiu D., Children G. 2011. Experiments with Past Materialities. BAR IS 2302. Archaeopress. Oxford.

Haimovici S. 2007. Mediterranean species discovered among the animal remains from Dobrogea province, Neolithic-Eneolithic period. Analele Stiintifice ale Universitătii “Al. I. Cuza” Iaşi LIII: 291-302.

Hălcescu C. 1995. Tezaurul de la Sultana. Culturăşsi civilizatie la Dunarea de Jos XIII-XIV: 11-15.

Higham T., Chapman J., Slavchev V., Gaydarska B., Honch N., Yordanov Y. and Dimitrova B. 2007. New perspectives on the Varna cemetery (Bulgaria) - AMS dates and social implications. Antiquity 81: 640-651.

Hurcombe L. M. 2007. Archaeological Artefacts as Material Culture. Routledge. London and New York.

Ivanov I. 1988. Die Ausgrabungen des Gräberfeldes von Varna. In A. Fol, J. Lichardus (eds.), Macht, Herrshaft, und Gold. Moderne Galerie des Saarland Museums, Saarbrücken: 49-66.

Ivanov I., Avramova M. 2000. Varna necropolis: The Dawn of European civilization. Agatho. Sofia.

Jones A. 2007. Memory and material culture. Cambridge University Press. Cambridge, New York, Melbourne, Madrid, Cape Town, Singapore, São Paulo.

Jones A., Bradley R. 1999. The significance of colour in European archaeology. Cambridge Archaeological Journal 9 (1): 112-113.

Jones A., MacGregor G. (eds.) 2002. Colouring the past. The Significance of colour in archaeological research. Berg. Oxford and New York.
Jovanović J. 1996. Eneolithic gold pendants in SouthEast Europe: their meaning and their chronology. In T. Kovács (ed.), Studien zur Mettalindustrie im Karpatenbecken und den banachbarten Regionen: Festschrift für Amália Mozsolics zum 85. Geburtstag. Magyar Nemzeti Múzeum, Budapest: 31-36.

Keates S. 2002. The flashing blade: Copper, colour and luminosity in North Italian Copper Age society. In A. Jones, G. MacGregor (eds.), Colouring the past. The Significance of colour in archaeological research. Berg, Oxford and New York: 109-125.

Kiparisi-Apostolika N. 2011. Spondylus Objects from Theopetra Cave, Greece: Imported or Local Production? In F. Ifantidis, M. Nikolaidou (eds.), Spondylus in prehistory. New data and approaches. Contributions to the archaeology of shell technologies. BAR IS 2216. Archaeopress, Oxford: 161-167.

Knapp B. 1998. Mediterranean maritime landscapes: transport, trade, and society on Late Bronze Age Cyprus. In S. Swiny, R. Hohlfelder, H. W. Swiny (eds.), Res Maritimae: Cyprus and the Eastern Mediterranean from Prehistory through the Roman Period. Cyprus American Archaeological Research Institute, Monograph 1. ASOR/Scholars Press, Atlanta: 153-162.

Koleseri S. 1798. Auraria Romana-Dacica. Ioan Michaelis Landerer. Sibiu.

Landolfi M. 2005. Cypraea pantherina. Gasteropode dell' Oceano indiano e ornmente della Civiltà Picena, In M. A. Borrello (ed.), Conchiglie e archeologia. Preistoria Alpina 40, Supp 1: 97-100.

Lazăr C., Andreescu R., Ignat T., Mărgărit M., Florea M. and Bălăşescu A. 2009. New data on the Eneolithic cemetery from Sultana-Malu Roşu (Călăraşi County, Romania). Studii de preistorie 6: 165-199.

Lichardus J. 1991. Das Gräberfeld von Varna im Rahmen des Totenrituals des Kodžaderm-Gumelniţa-Karanovo VI-Komplexes. In J. Lichardus (ed.), Die Kupferzeit als historische Epoche: Symposium Saarbrücken und Otzenhausen 6.-13.11.1988. Saarbrücker Breiträge zur Altertumskunde, 55. Dr. Rudolf Habelt GmbH, Bonn: 167-194.

Lynch F. 1998. Colour in prehistoric archaeology. In A. Gibson, D. D. A. Simpson (eds.), Prehistoric ritual and religion. Sutton. Stroud: 62-67.

Meskell L. (ed.) 2005. Archaeologies of materiality. Blackwell. Oxford.

Miller D. (ed.) 2005. Materiality: An Introduction. Duke University Press. Durham and London. 
Müller J. 2012. Tells, Fire, and Copper as Social Technologies. In R. Hofmann, F-K. Moetz, J. Müller (eds.), Tells: Social and Environmental Space. Proceedings of the International Workshop Socio-Environmental Dynamics over the Last 12,000 Years: The Creation of Landscapes II. Verlag Dr. Rudolf Habelt GmbH, Bonn: 4752.

Noble J. V. 1988. The technique of painted pottery. Thames and Hudson. New York.

Owoc M. A. 2002. Munselling the mound: The use of soil metaphor in British Bronze Age funerary ritual. In A. Jones, G. MacGregor (eds.), Colouring the Past. The Significance of colour in archaeological research. Berg, Oxford \& New York: 127-140.

Pernicka E., Anthony D. W. 2010. The invention of copper metallurgy and Copper Age of Old Europe. In D. W. Anthony, and J. Y. Chi (eds.), The Lost World of Old Europe. The Danube Valley, 5000-3500 BC. Princeton University Press, Princeton and 0xford: 163-177.

Pope G. T., Goto Y. 1993. European seashells II. Scaphopoda, Bivalvia, Cephalopoda. Weisbaden.

Popovici D. N. 2010. Copper Age traditions north of the Danube River, pp. In D. W. Anthony and J. Y. Chi (eds.), The Lost World of Old Europe. The Danube Valley, 50003500 BC. Princeton University Press, Princeton and Oxford: 91-111.

Rapp G. 2009. Archaeomineralogy. Springer-Verlag. Berlin, Heidelberg.

Renfrew C., Scarre C. (eds.) 1998. Cognition and material culture: the archaeology of symbolic storage. McDonald Institute for Archaeological Research, University of Cambridge. Cambridge.

Schiffer M. B., Miller A. R. 1999. The Material life of human beings, Artifacts, behavior and communication. Routledge. London and New York.
Séfériadès M. L. 1995. Le commerce des spondyles de la mer Égée à la Manche. Archéologia 309: 42-50.

2011. Protohistoric Spondylus gaederopus L. shell: some considerations on the earliest European long-distance exchanges related to shamanism. In A. Vianello (ed.), Exotica in the Mediterranean. Oxbow Books, Oxford: 3-12.

Siklosi Z., Csengeri P. 2011. Reconsideration of Spondylus usage in the middle and late Neolithic of the Carpathian basin. In F. Ifantidis, M. Nikolaidou (eds.), Spondylus in prehistory. New data and approaches. Contributions to the archaeology of shell technologies. BAR IS 2216. Archaeopress, Oxford: 47-62.

Slavchev V. 2010. The Varna Eneolithic cemetery in the context of the Late Copper Age in the East Balkans. In D. W. Anthony, J. Y. Chi (eds.), The Lost World of Old Europe. The Danube Valley, 5000-3500 BC. Princeton University Press, Princeton and 0xford: 193-210.

Tilley C. 2004. The materiality of stone: explorations in landscape phenomenology. Berg. Oxford.

Todorova H. 1982. Kupferzeitliche Siedlungen in Nordostbulgarien. C. H. Beck. München.

Tsuneki A. 1989. The manufacture of Spondylus shell objects at Neolithic Dimini, Greece. Orient $X X V: 1-21$.

Ursachi V. 1991. Le Paléolithique et le Néolithique de la Roumanie en context européen. Bibliotheca Archaeologica Iassiensis. Iasi.

Veblen T. 1994. The theory of the leisure class. An economic study of institutions. Penguin Books. New York.

Vianello A. (ed.) 2010. Exotica in the Mediterranean. 0xbow Books. Oxford. 